\title{
Beneficiation research on a low grade linnaeite ore with hema- tite-pyrite type
}

\author{
Xinfang Zhang, Qinqin Wang, Chengdong Wang, Lang Zhu, Shujie Shi, Niao Wang, Chunying Li and Guiming Shi* \\ College of Chemistry Biology and Environment, Yuxi Normal University, Yuxi, Yunnan, 653100, China
}

\begin{abstract}
Mineralogy and separation experiments were carried out for a low-grade linnaeite ore $(0.052 \%)$, which belonged to limonite-hematite-pyrite type complex mineral. Under the grinding fineness of $80 \%$ $0.074 \mathrm{~mm}$, linnaeite concentrate which contained cobalt grade of $0.51 \%$, recovery rate of $80.99 \%$, sulfur grade of $23.79 \%$, recovery of $88.03 \%$ was obtained by closed-circuit processes of one roughing, two scaenging and one cleaning, which used sulfate acid (4500 g/t) and copper sulfate (300 g/t) as activator, sodium silicate $(1000 \mathrm{~g} / \mathrm{t})$ and $\mathrm{CMC}(30 \mathrm{~g} / \mathrm{t})$ as inhibitor, ethyl xanthate $(100 \mathrm{~g} / \mathrm{t})$ and butyl xanthate $(100 \mathrm{~g} / \mathrm{t})$ as collector, 2\# oil (40 g/t) as forther in roughing, no agent in cleaing and first scavenging, used ethyl xanthate $(50 \mathrm{~g} / \mathrm{t})$ and butyl xanthate $(50 \mathrm{~g} / \mathrm{t})$ as collector, $2 \#$ oil $(20 \mathrm{~g} / \mathrm{t})$ as forther in second scavenging.
\end{abstract}

\section{Introduction}

Cobalt is one of the important strategic mineral in the world, it has high temperature resistance, corrosion resistance, high strength and strong magnetic etc, which are often used to make hard heat-resistant alloy, magnetic alloy, tungsten carbide substrate or adhesive, which widely used in power battery, ceramics, electric machinery, machinery, chemicals, aviation and aerospace industries, it is of special significance in the national economy and social development.Cobalt is difficult to form an independent economic deposit, most of which is associated with copper, nickel and pyrite deposits, the reserves of land resources are relatively small.

In this paper, the hematite-pyrite type cobalt sulfide ore was studied. Although the total iron of the ore reached $23.93 \%$, more than $90 \%$ of it was iron oxide mineral, which was difficult to be used. The grade of other metallic elements was low and had little use value, and only sulfur and cobalt had certain use value. Since cobalt mainly existing in pyrite and is replaced by isomorphism, the carrier of cobalt in recovered samples must be pyrite, but the content of cobalt in pyrite is low and it is difficult to obtain qualified cobalt sulfide concentrate. Therefore, this paper mixed the cobalt sulfide mineral with other sulphides to obtain mixed concentrate.

\section{Ore properties}

\subsection{Sample chemical analysis}

The results of multi-element analysis and phase analysis of raw ore can be found in Table 1, Table 2.

According to Table 1 and Table 2, although the total iron of the mine reaches $23.34 \%$, more than $90 \%$ of the ore is iron oxide mineral, which is difficult to utilize, and other metal elements are of low grade and have little value in utilization. Cobalt as an important metal element required for new energy batteries can be used as a combined recovery of cobalt sulfur concentrate without separation recovery value.

Table 1. Multi-element analysis results of raw ore (\%).

\begin{tabular}{llllllll}
\hline Component & $\mathrm{TFe}$ & $\mathrm{Co}$ & $\mathrm{CaO}$ & $\mathrm{SiO}_{2}$ & $\mathrm{Al}_{2} \mathrm{O}_{3}$ & $\mathrm{MgO}$ & $\mathrm{S}$ \\
\hline Content & 23.93 & 0.052 & 3.72 & 36.18 & 7.30 & 2.18 & 2.19 \\
\hline Component & $\mathrm{P}$ & $\mathrm{Cu}$ & $\mathrm{Pb}$ & $\mathrm{Zn}$ & $\mathrm{As}$ & $\mathrm{Au}^{\mathrm{a}}$ & \\
\hline Content & 0.036 & 0.019 & 0.14 & 0.18 & 0.005 & 0.20 & \\
\hline${ }^{\mathrm{a}}$ unit: $\mathrm{g} / \mathrm{t}$ & & & & & & &
\end{tabular}


Table 2. Results of iron phase analysis (\%).

\begin{tabular}{llllllll}
\hline Mineral name & $\mathrm{Fe}_{3} \mathrm{O}_{4}$ & $\mathrm{Fe}_{2} \mathrm{O}_{3}$ & $\mathrm{FeS}_{2}$ & $\mathrm{Fe}_{n} \mathrm{~S}_{\mathrm{n}+1}$ & $\mathrm{FeCO}_{3}$ & $\mathrm{FeSiO}_{3}$ & $\mathrm{TFe}$ \\
\hline Iron content in iron phase & 0.21 & 19.27 & 2.28 & 0.11 & 0.25 & 1.22 & 23.34 \\
\hline Distribution & 0.90 & 82.56 & 9.77 & 0.47 & 1.07 & 5.23 & 100 \\
\hline
\end{tabular}

\subsection{Ore composition and structure}

The metallic minerals in the sample are mainly hematite, limonite, followed by pyrite, gangue minerals are quartz, clay minerals, carbonate minerals, a small amount of tourmaline, tululite, etc.

Cobalt-bearing minerals: cobalt-bearing minerals are small pyrite or pyroxenite inclusions (particle size $<0.02$ $\mathrm{mm}$ ) encased in pyrite, followed by isomorphism in pyrite. A few are filled in hematite fissures (which can be recovered by strengthening fine grinding).

Hematite: grey-white, it-shaped crystal; granular, a few leaf-shaped, particle size $0.001 \times 0.05 \mathrm{~mm}$, content 45 $48 \%$.

Limonite: grey microstrip light blue, fibrouscryptocrystalline aggregate, aggregate size $0.005 \times 0.35$ $\mathrm{mm}$, with brownish red internal reflection color, distributed between hematite and gangue mineral particles, metasomatic hematite, the metasomatism residual inclusions containing hematite in some aggregates contain $35-$ $40 \%$.

Pyrite: light copper yellow, semi-autogenous crystal, mostly pentagonal dodecahedral crystal, some of the crystals are fragmentation, particle size $0.02 \times 1.2 \mathrm{~mm}$, is star-shaped, pulse-like distribution, content is $8-10 \%$.

\section{Experimental results and discus- sion}

\subsection{Grinding fineness test}

Flotation tests are carried out under different fineness. The test conditions and processes are shown in Figure 1, and the test results are shown in Figure 2.

It can be seen from Figure 2 that with the increase of grinding fineness, the content of cobalt sulfide in concentrate grade increases, and the recovery rate increases at first and then decreases, and reaches the maximum when the grinding fineness reaches $-0.074 \mathrm{~mm} 80 \%$. At this time, the cobalt content of crude concentrate is $0.28 \%$ and the recovery is over $41 \%$, which indicates that cobalt sulphide in ore is easier to be separated. At the same time, cobalt is high in sulfur, low in cobalt and low in sulfur, indicating that cobalt is mainly associated with pyrite, and that cobalt is enriched in a sulfur concentrate by strengthening recovery of sulfur.

\subsection{Study on the Type and dosage of Activator}

At grinding fineness of $-0.074 \mathrm{~mm} 80 \%$, the test conditions were as follows: type and dosage of activator, collector butyl xanthate $200 \mathrm{~g} / \mathrm{t}, 2 \#$ oil $40 \mathrm{~g} / \mathrm{t}$. The test procedure is shown in Figure 1, and the test results are shown in Figure 3.

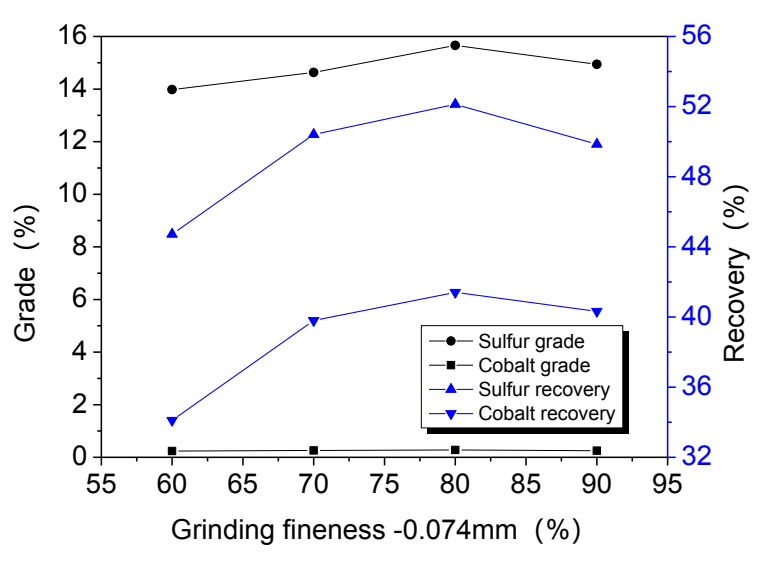

Figure 2. Results of grinding fineness test.
Figure 1. Flowchart of grinding fineness test.

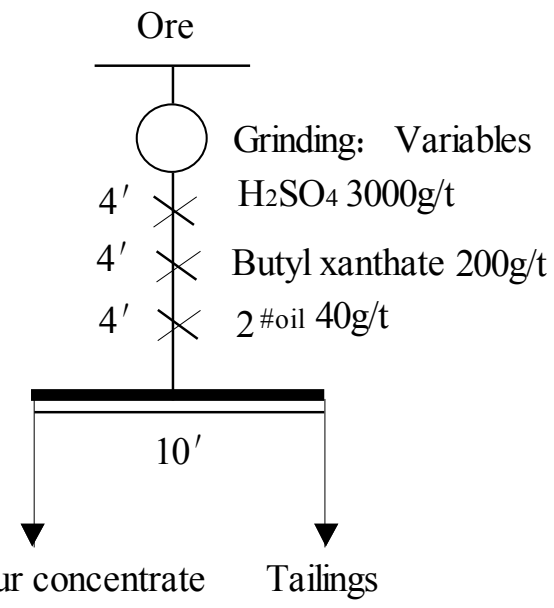




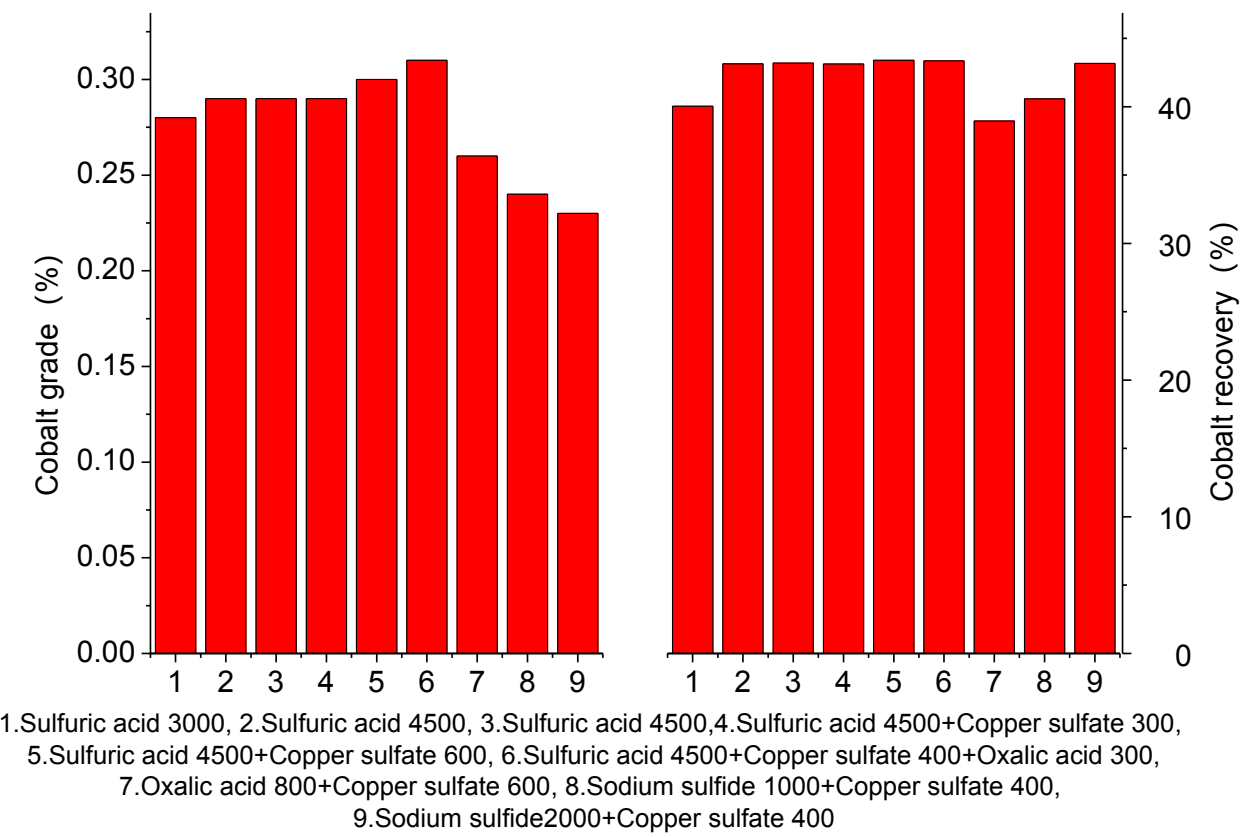

Figure 3. Results of activator type and dosage.

As can be seen from Figure 3, the copper sulfate is selected to be better than the alkaline medium in the acid medium, and when the amount of the sulfuric acid is $4500 \mathrm{~g} / \mathrm{t}$, the use effect of the copper sulfate mixed with different amounts is not small, and the comprehensive consideration cost is finally determined to adopt the sulfuric acid $4500 \mathrm{~g} / \mathrm{t}$ and copper sulfate $300 \mathrm{~g} / \mathrm{t}$, at the time, the cobalt grade is $0.29 \%$, the recovery rate is $43.12 \%$.

\subsection{Study on the types and dosage of Inhibitors}

At grinding fineness of $-0.074 \mathrm{~mm} 80 \%$, the test conditions were as follows: the activator is sulfate acid 4500 $\mathrm{g} / \mathrm{t}$, copper sulfate $300 \mathrm{~g} / \mathrm{t}$, the type and dosage of inhibitor, the collector butyl xanthate $200 \mathrm{~g} / \mathrm{t}$, the $2 \#$ oil $40 \mathrm{~g} / \mathrm{t}$, the test flow as shown in Figure 1, the test results are shown in Figure 4.

From Figure 4, it can be seen that the best effect is obtained by using water glass $\mathrm{CMC}$ as inhibitor, when the dosage is $1000 \mathrm{~g} / \mathrm{t}$ and $30 \mathrm{~g} / \mathrm{t}$, the cobalt grade is $0.33 \%$, and the recovery rate is $44.12 \%$.

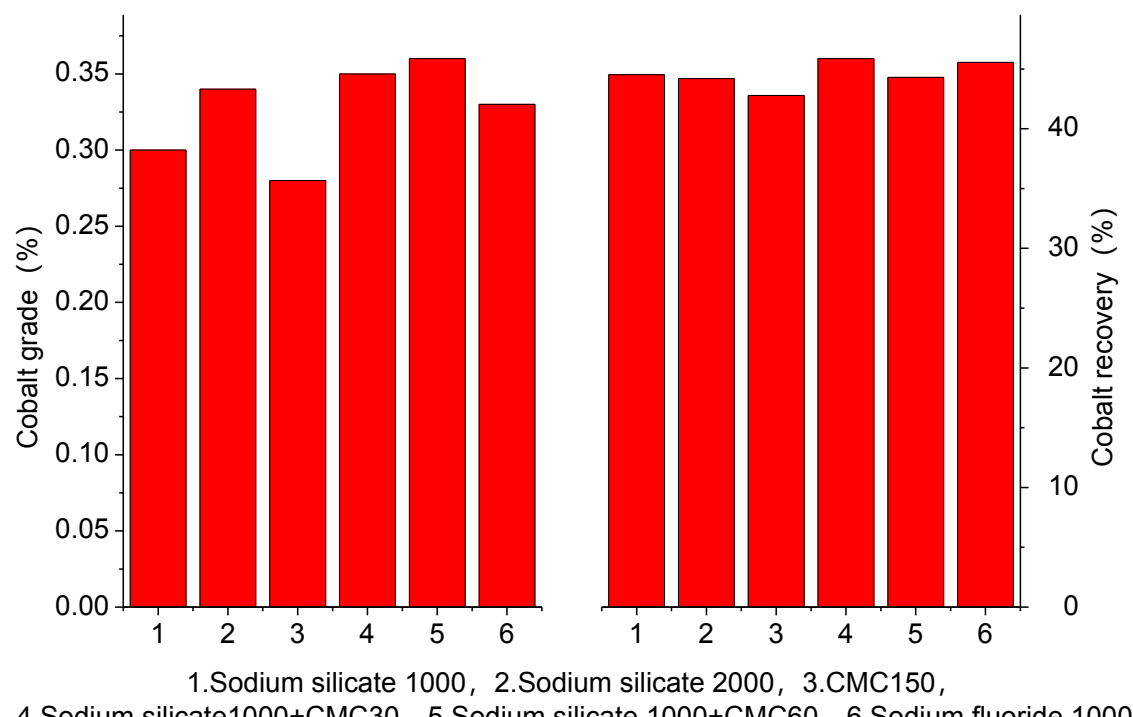

Figure 4. Results of inhibitor type and dosage. 


\subsection{Study on the types and dosage of Collector}

At the grinding fineness of $-0.074 \mathrm{~mm} 80 \%$, the test conditions were as follows: the activator is sulfate acid $4500 \mathrm{~g} / \mathrm{t}$, copper sulfate $300 \mathrm{~g} / \mathrm{t}$, the inhibitor is water glass $1000 \mathrm{~g} / \mathrm{t}$ and $\mathrm{CMC} 30 \mathrm{~g} / \mathrm{t}$, the type and dosage of collector are variable, $2 \#$ oil is $40 \mathrm{~g} / \mathrm{t}$, the test procedure is shown in Figure 1, the test results are shown in Figure 5 .

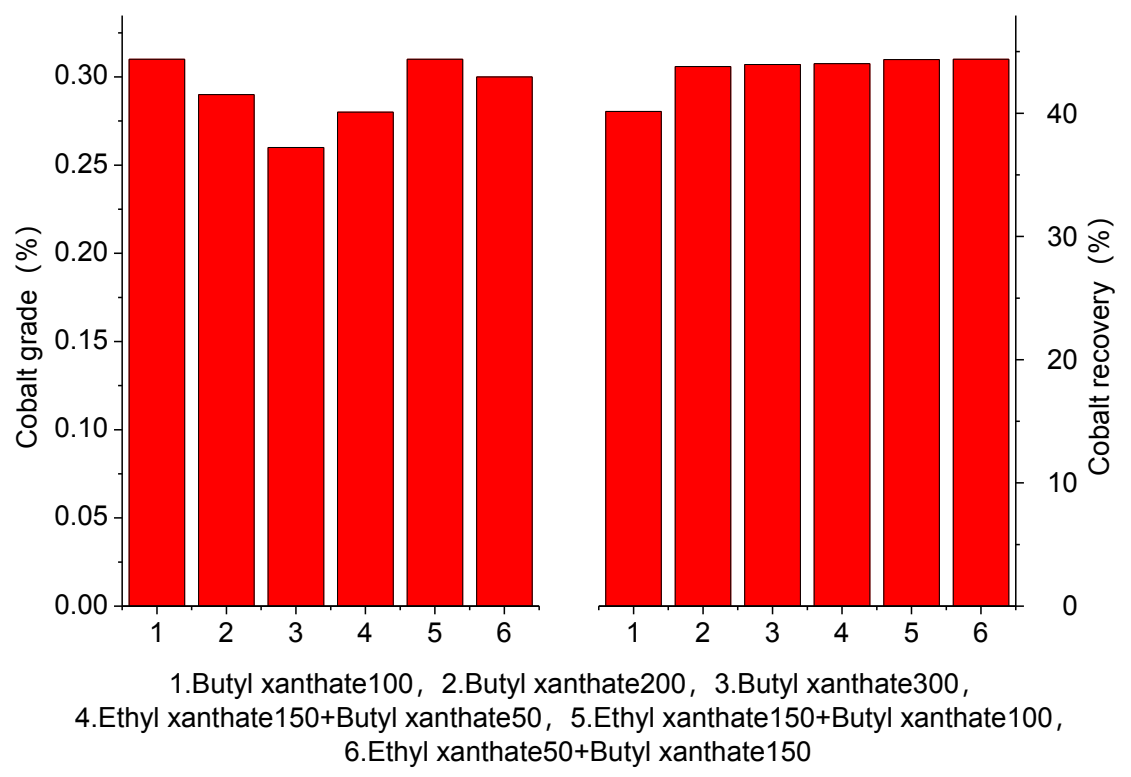

Figure 5. Results of collector type and dosage.

From Figure 5, it can be seen that the best effect is obtained by using ethyl xanthate butyl xanthate as collector, and the cobalt grade is $0.32 \%$ and the recovery rate is $44.36 \%$.

\subsection{Scavenging test}

At grinding fineness of $-0.074 \mathrm{~mm} 80 \%$, the test conditions were as follows: the activator is sulfate acid 4500 $\mathrm{g} / \mathrm{t}$ and copper sulfate $300 \mathrm{~g} / \mathrm{t}$, the inhibitor is water glass $1000 \mathrm{~g} / \mathrm{t}$ and CMC $300 \mathrm{~g} / \mathrm{t}$, the collector ethyl xanthate
$100 \mathrm{~g} / \mathrm{t}$ and butyl xanthate are $100 \mathrm{~g} / \mathrm{t}$, the $2 \#$ oil is $40 \mathrm{~g} / \mathrm{t}$, two scavenging operations (no chemicals added) are carried out, and the test results are shown in Table 3.

As can be seen from table 3 , the cumulative recovery rate of the three concentrates reached $84.42 \%$ with the total flotation time of 13 min after two scavenging, indicating that the sulfur concentrate is basically recovered by two scavenging, so the two scavenging are finally determined.

Table 3. Results of scavenging times.

\begin{tabular}{lllllll}
\hline \multirow{2}{*}{ Produce name } & \multirow{2}{*}{ Yield } & \multicolumn{2}{l}{ Grade } & \multicolumn{3}{l}{ Recovery } \\
\cline { 3 - 4 } \cline { 5 - 6 } Concentration 1 & 6.97 & 0.340 & 17.01 & & 45.57 & 52.03 \\
Concentration 2 & 6.69 & 0.196 & 9.88 & & 25.22 & 28.99 \\
Concentration 3 & 5.32 & 0.133 & 3.72 & & 13.63 & 8.68 \\
Taling & 81.02 & 0.010 & 0.29 & & 15.58 & 10.30 \\
Ore & 100.00 & 0.052 & 2.28 & & 100.00 & 100.00 \\
\hline
\end{tabular}

\subsection{Cleaning test}

At grinding fineness of $-0.074 \mathrm{~mm} 80 \%$, the test conditions were as follows: the activator is sulfate acid 4500 $\mathrm{g} / \mathrm{t}$ and copper sulfate $300 \mathrm{~g} / \mathrm{t}$, the inhibitor is water glass
$1000 \mathrm{~g} / \mathrm{t}$ and CMC $30 \mathrm{~g} / \mathrm{t}$, the collector is ethyl xanthate $100 \mathrm{~g} / \mathrm{t}$ and butyl xanthate $100 \mathrm{~g} / \mathrm{t}$, and the $2 \#$ oil is $40 \mathrm{~g} / \mathrm{g}$. two cleaning operations (no chemicals added) are carried out, and the test results are shown in Table 4. 
Table 4. Results of cleaning times.

\begin{tabular}{lllllll}
\hline \multirow{2}{*}{ Produce name } & \multirow{2}{*}{ Yield } & \multicolumn{2}{l}{ Grade } & \multicolumn{3}{l}{ Recovery } \\
\cline { 3 - 4 } \cline { 5 - 6 } & & Co & S & Co & S \\
\hline Concentration & 3.46 & 0.60 & 28.89 & 39.92 & 43.84 \\
Middling 1 & 1.12 & 0.10 & 7.62 & 2.15 & 3.74 \\
Middling 2 & 2.30 & 0.054 & 4.18 & & 2.41 & 4.22 \\
Tailing & 93.12 & 0.031 & 1.18 & & 55.51 & 48.19 \\
Ore & 100.00 & 0.052 & 2.28 & 100.00 & 100.00 \\
\hline
\end{tabular}

Table 4 shows that after only one cleaning operation, the combined grade of concentrate and ore one is $0.48 \%$, which basically meets the quality requirements of the first grade products of cobalt sulphide concentrate $(\mathrm{Co} \geq$ $0.45 \%, \mathrm{~S} \geq 27 \%$ ). Considering the selection cost and process flow, we decide to adopt only one cleaning operation.

\subsection{Closed circuit test}

The closed-circuit test results are shown in Table 5.

Table 5. Results of closed-circuit

\begin{tabular}{llllll}
\hline \multirow{2}{*}{ Produce name } & \multirow{2}{*}{ Yield } & \multicolumn{2}{l}{ Grade } & \multicolumn{2}{c}{ Recovery } \\
\cline { 3 - 6 } \cline { 5 - 6 } Concentration & 8.40 & 0.51 & 23.79 & 80.99 & 88.03 \\
\hline Tailing & 91.6 & 0.011 & 0.30 & 19.01 & 11.97 \\
\hline Ore & 100.00 & 0.053 & 2.27 & 100.00 & 100.00 \\
\hline
\end{tabular}

As can be seen from Table 5, through the closed circuit process of one roughing, one cleaning and two scavengings, the grinding fineness of $-0.074 \mathrm{~mm} 80 \%$, the activated agent of crude separation is $300 \mathrm{~g} / \mathrm{t}$ copper sulfate, and the inhibitor is water glass $1000 \mathrm{~g} / \mathrm{t}$ and CMC $30 \mathrm{~g} / \mathrm{t}$, the collector ethyl xanthate $100 \mathrm{~g} / \mathrm{t}$ and butyl xanthate $100 \mathrm{~g} / \mathrm{t}, 2 \#$ oil $40 \mathrm{~g} / \mathrm{t}$, cleaning, scavenging one blank flotation, scavening two using collector ethyl xanthate $50 \mathrm{~g} / \mathrm{t}$ and butyl xanthate $50 \mathrm{~g} / \mathrm{t}, 2 \#$ oil $20 \mathrm{~g} / \mathrm{t}$, a better index of cobalt content $0.51 \%$, recovery $80.99 \%$, sulfur $23.79 \%$ and recovery $88.03 \%$ are obtained.

\section{Conclusions}

(1) The main mineral composition of the sample is hematite-pyrite type mineral, hematite, pyrite is other-shaped granular structure, implicit crystal and leaf-like structure: pyrite is distributed in limonite or hematite aggregate as metasomatism residue. The ore structure mainly has strip structure, breccia, and disseminated structure. Although the total iron of this mine is $23.93 \%$, more than $90 \%$ are iron oxide minerals, which are difficult to use. Cobalt as the important metal element needed for new energy batteries co-exists with pyrite can be recovered by mixing with other sulphide ores. The grade of other metal elements is lower than that of other metal elements.

(2) Under the grinding fineness of $-0.074 \mathrm{~mm} 80 \%$, linnaeite concentrate which contained cobalt grade of $0.51 \%$, recovery rate of $80.99 \%$, sulfur grade of $23.79 \%$, recovery of $88.03 \%$ was obtained by closed-circuit processes of one roughing, two scavenging and one cleaning, which used sulfate acie (4500 g/t) and copper sulfate $(300 \mathrm{~g} / \mathrm{t})$ as activator, sodium silicate $(1000 \mathrm{~g} / \mathrm{t})$ and CMC $(30 \mathrm{~g} / \mathrm{t})$ as inhibitor, ethyl xanthate $(100 \mathrm{~g} / \mathrm{t})$ and butyl xanthate $(100 \mathrm{~g} / \mathrm{t})$ as collector, $2 \#$ oil $(40 \mathrm{~g} / \mathrm{t})$ as forther in roughing, no agent in cleaing and first scavenging, used ethyl xanthate $(50 \mathrm{~g} / \mathrm{t})$ and butyl xanthate
$(50 \mathrm{~g} / \mathrm{t})$ as collector, $2 \#$ oil $(20 \mathrm{~g} / \mathrm{t})$ as forther in second scavenging.

\section{Acknowledgements}

We gratefully acknowledge the financial assistance of Yunnan Provincial Education Department Project (No: 2019J0738), National natural science foundation (No: 51964044), Yunnan Local Colleges Applied Basic Research Projects (No: 2018FH001-051).

\section{References}

1. Liu, Q.W., Sha, J.H., Yan, J.J., et al. (2018) Risk Assessment and Governance of Cobalt Resources Supply in China. China Min. Mag., 27: 50-56.

2. Li, Y., Zhou, Y.J., Zhang, Y.F. (2014) The Future Supply Situation Analysis of Global Cobalt Resources. China Min. Mag., 23: 1-4.

3. Lai, W.Q., Chen, S.B., Wei, Z.H. (2016) Recovery of Sulfur and Cobalt from Tailings with High Sulfur in Alkali Pulp. Nonferrous Met. (Miner. Process. Sect.), 5: 45-48.

4. Liu, J. (2013) Comprehensive Recovery of Sulfide Minerals from Tailings of Iron Concentration. Min. Metall. Eng., 33: 50-53.

5. Zhan, X.Y. (2015) Experimental Study on Recovery of Copper, Cobalt and Sulfur in the Beneficiation Process of Iron Ore. Min. Metall, 24: 22-25.

6. Kongolo, K., Kipoka, M., Minanga, K., et al. (2003) Improving the Efficiency of Oxide Copper-Cobalt Ores Flotation by Combination of Sulphidisers. Miner. Eng., 16: 1023-1026.

7. Shengo, L.M., Gaydardzhiev, S., Kalenga, N.M. (2014) Assessment of Water Quality Effects on Flo- 
tation of Copper-cobalt Oxide ore. Miner. Eng., 65: 145-148.

8. Léon, Z., Fanny, L., Jean, F, et al. (2015) Possibilities for Co (III) Dissolution from an Oxidized Ore through Simultaneous Bioleaching of Pyrite. Miner. Eng., 75: 54-62.

9. Foucher, S., Battaglia-Brunet, F., d'Hugues, P. (2003) Evolution of the Bacterial Population during the Batch Bioleaching of a Cobaltiferous Pyrite in a Suspended-solids Bubble Column and Comparison with a Mechanically Agitated Reactor. Hydrometallurgy, 71:5.

10. Bienvenu, I.M., Meschac-Bill, K., Alexis M.D.T. (2017) Comparative Study of Approaches based on the Taguchi and ANOVA for Optimising the Leaching of Copper-Cobalt Flotation Tailings. Chem. Eng. Commun., 204: 512-521. 